Федун I. Л. [1 ORCID ID: 0000-0002-1012-9970], д.е.н., професор кафедри світової економіки

Кравець К. П. [1; ORCID ID: 0000-0002-6850-9378], к.е.н., доцент кафедри світової економіки

${ }^{1}$ Київський національний торговельно-економічний університет, м. Київ

\title{
СИНЕРГІЧНІ ЕФЕКТИ В ПРОЦЕСАХ КОНЦЕНТРАЦІЇ ВИРОБНИЦТВА
}

У статті розглянуто теоретичні аспекти прояву синергічних ефектів при сучасних концентраційних процесах. Досліджено основні форми прояву синергічних ефектів на прикладі харчової промисловості. Розглянуто основні форми прояву синергетичних ефектів. Сформовано теоретичні підходи до сутності понять «синергетика» та «синергетичні ефекти». Наведено методичний інструментарій дослідження синергетичних ефектів. Розглянуто синергетичні ефекти в розрізі позитивного та негативного результату.

Ключові слова: концентрація виробництва; синергія; синергетичні ефекти; харчова промисловість.

Постановка проблеми. Процеси глобалізації та концентрації виробництва відбуваються зараз у всіх сферах економіки. Вони якісно і кількісно впливають як на окреме підприємство, так і на економіку держави загалом. Актуальність теми дослідження зумовлена сучасними викликами, що виникли перед українською економікою та пов'язані насамперед із необхідністю глибокої модернізації та переходу на нову - інноваційну - траєкторію розвитку. Вирішення цих завдань ускладнено тим, що функціонування української економіки характеризується низкою фундаментальних протиріч. Серед породжуваних ними негативних особливостей вітчизняної економіки - недостатньо ефективні державне управління, захист прав власності, умови для інтенсивного розвитку підприємництва, високий рівень корупції. Аналіз цих проблем в сучасних умовах вимагає урахування синергетичних ефектів, що дозволяє підвищити обґрунтованість та дієвість економічної політики. Аналогічно цьому, при дослідженні економічної циклічності необхідно брати до уваги їі синергетичну природу, яка надає істотний вплив на особливості прояву циклічної динаміки в реальних економічних системах.

Нелінійність і складність, що характеризують економічну 
систему, а також наявність в ній величезної кількості зворотних зв'язків обумовлюють синергетичну природу багатьох економічних явищ і призводять до виникнення численних синергетичних ефектів, що змінюють якісну сторону функціонування національної економіки. Дослідження економічної системи без належної уваги до таких ефектів веде до неповного або навіть некоректного розуміння притаманних їй об'єктивних закономірностей і недостатньо ефективному управлінню на практиці.

Використання методології синергетики в економічних дослідженнях нині стає все більш поширеним, оскільки дозволяє поновому, у порівнянні з більш ранніми методологічними підходами, виявляти нерегулярні ефекти, існуючі в економічній дійсності, більш глибоко розуміти природу їх виникнення, ідентифікувати їх і відповідним чином впливати на перебіг економічних процесів. Осмислення природи і особливостей прояву синергетичних ефектів дозволяє організовувати управління економікою на якісно новому рівні, заснованому на уявленнях дискретності і стійкості траєкторій економічного розвитку. Присутність синергетичних ефектів в економіці вимагає нових підходів до прогнозування, планування, регулювання на різних рівнях - від економіки окремої фірми до економіки всієї країни.

В основі вивчення природи, механізмів прояву та змісту синергетичних ефектів лежать фундаментальні роботи Г.Ніколіс, І. Запрожина, І.Стенгерс, Г.Хакена, а також дослідження вітчизняних вчених В. Арнольда, Є.Князєвої, С. Курдюмова, Г. Малінецького, Д. Трубецькова, Г.Шустера. Ідеї синергетики стосовно вивчення економічних систем знайшли істотний розвиток у роботах В.-Б. Занга, Е. Петерса та ін.

Водночас слід визнати, що між роботами, присвяченими побудові кількісних моделей синергетичних ефектів в економіці, і роботами, що зачіпають виключно якісні аспекти таких ефектів, в даний час існує великий розрив. Так, у більшості кількісних досліджень синергетичних ефектів в економіці наводиться недостатнє емпіричне обґрунтування отриманих висновків, а також порівняно слабко розкриті якісні особливості і наслідки виникнення в економічній системі синергетичних ефектів. Багато якісні дослідження синергетичних явищ в економіці, навпаки, надмірно абстрагуються від їх раціональної основи. Таким чином, потреба у вивченні якісного боку синергетичних ефектів в економіці 3 урахуванням їх раціональної природи, а також в емпіричній перевірці гіпотез про існування і особливості прояву синергетичних 
ефектів в українській економіці визначила вибір теми, мету і завдання дослідження.

Постановка завдання. Вивчення особливостей прояву синергетичних ефектів в сучасній економіці дозволить глибше проаналізувати фактори, що перешкоджають переведенню національної економіки на інноваційний шлях розвитку; осмислити особливості економічної циклічності, викликані їі синергетичною природою; розвинути теоретичну базу для розробки економічної політики, націленої на стимулювання ефективного і якісного економічного зростання за рахунок розвитку приватної ініціативи, що також виявляється у формі регіональних кластерів, які самоорганізовуються.

Основні результати дослідження. Вивчення синергетичних ефектів в економіці базується на висновках кейнсіанської, посткейнсіанської, неокласичної, інституціональної, еволюційної економічних теорій, а також на досягненнях сучасної синергетики і математики.

Водночас слід визнати, що між роботами, присвяченими побудові кількісних моделей синергетичних ефектів в економіці, і роботами, що зачіпають виключно якісні аспекти таких ефектів, нині існує великий розрив. Так, у більшості кількісних досліджень синергетичних ефектів в економіці наводиться недостатнє емпіричне обґрунтування отриманих висновків, а також порівняно слабко розкриті якісні особливості і наслідки виникнення в економічній системі синергетичних ефектів. Якісні дослідження синергетичних явищ в економіці, навпаки, надмірно абстрагуються від їх раціональної основи. Таким чином, потреба у вивченні якісного боку синергетичних ефектів в економіці з урахуванням їх раціональної природи, а також в емпіричній перевірці гіпотез про існування і особливості прояву синергетичних ефектів в українській економіці визначила вибір теми, мету і завдання дослідження.

Синергетичний ефект в економіці $є$ результатом кооперативної дії елементів економічної системи, що призводить до зміни якісного стану економіки і траєкторії іï розвитку, а також до утримання економіки на стійкій траєкторії розвитку, незважаючи на екзогенні шоки і ендогенні флуктуації. Таке розуміння синергетичного ефекту в економіці дозволяє побудувати досить широку класифікацію синергетичних ефектів, не обмежується лише випадками, коли $2+2=5$ і коли виявляється більш доречним говорити про синергічний (тобто про синергіi), а не синергетичний ефект [1, С. 32]. 
Ураховуючи певну неусталеність понятійного апарату синергічної концепції, пропонуємо у межах нашого дослідження під синергічним ефектом концентрації виробництва підприємств розуміти зміну, що полягає у поєднанні таких елементів укрупнення, при яких потенціал буде значно перевищувати (чи знижувати) суму потенціалів, що входять до іï елементів, що зумовлюється виникненням так званого системного ефекту (ефекту емерджентності) та супроводжується частковою втратою кожним 3 елементів їх стратегічної автономності (або незалежності у прийнятті стратегічних рішень). Одразу слід зауважити, що подібний ефект може мати як позитивний (безпосередньо синергійний), так і негативний (або дисинергійний) прояв, про що у відповідних теоретичних дослідженнях згадується нечасто. Дисинергія може бути обумовлена високими витратами, що виникають в процесі укрупнення підприємства або внаслідок зниження керованості більш складною системою.

На нашу думку, синергетичний ефект не можна розглядати тільки як інтеграцію вигод від об'єднання підприємства, адже часткові вигоди від функціонування можуть проявлятися у кожного підприємства окремо, а синергетичний ефект передбачає, що в ході зосередження виробництва виникають такі вигоди, які зумовлюють приріст вартості об'єднаного підприємства, оскільки фактори виробництва використовуються ефективніше. Такі поширені визначення синергетичного ефекту, як «комбінація бізнесів, тобто два плюс два дорівнює п'яти», або «інтеграція вигод від об'єднання стратегій та економії на масштабі», є некоректними і вводять в оману. Очевидно, що ефект синергії виникає тільки в тому разі, коли в результаті об'єднання у підприємств з'являється суттєво нова компетенція або стратегічна перевага, яка не доступна його конкурентам, що й обумовлює більш високу оцінку вартості підприємства з боку ринку.

Тому, враховуючи певну неусталеність понятійного апарату синергічної концепції, пропонуємо під «синергетичним ефектом концентрації виробництва на підприємствах» розуміти зміну, що полягає у поєднанні таких елементів укрупнення, за яких потенціал буде значно перевищувати (чи знижувати) суму потенціалів, які входять до іï елементів, що зумовлюється виникненням системного ефекту (ефекту емерджентності) та супроводжується частковою втратою кожним 3 елементів їх стратегічної автономності (або незалежності у прийнятті стратегічних рішень). Необхідно зауважити, що ефект може мати як позитивний (безпосередньо синергетичний), так і негативний (дисинергетичний) прояв, про що у відповідних теоретичних дослідженнях згадується нечасто. 
Дисинергія може бути обумовлена високими витратами, що виникають у процесі укрупнення підприємства або внаслідок зниження керованості більш складною системою.

1. Позитивний ефект можна записати у вигляді такої нерівності «2+2>5». На нашу думку, позитивний синергійний ефект при укрупненні виробництва підприємств харчової промисловості проявляється у скороченні витрат за заданого рівня доходу, збільшення доходів за заданого рівня витрат або в разі збільшення доходів з одночасним скороченням витрат (ефект «подвійного синергізму») [7, С. 11].

Наведемо приклади позитивного синергічного ефекту в харчовій промисловості. Швейцарська компанія Nestle у 1998 р. придбала лідера вітчизняного кондитерського ринку фабрику «Світоч», у 2003 р. була куплена компанія «Волинь-холдинг» (ТМ «Торчин»), а в 2010 р. - ТОВ «Техноком» (ТМ «Мівіна»). Синергічний ефект від об'єднання цих компаній виражається у правильному розподілі зусиль. Керівництво компанії здійснюється 3 єдиного офісу (починаючи з розробки стратегії і закінчуючи поставками сировини та упакування), а тому фабрики можуть сконцентруватися лише на виробництві. Завдяки об'єднанню в українських компаній з'явилися джерела дешевшої сировини, зникли проблеми з обіговими коштами. Водночас Nestle змогла не тільки розширити асортиментну лінійку солодощів в Україні, але й вийти в лідери українського ринку соусів.

Ще одним прикладом є придбання американським концерном РерsiCo одного з лідерів вітчизняного ринку соків - компанії «Сандора». Новий генеральний директор «Сандори» визначає синергію, яка отримана внаслідок угоди тим, що у PepsiCo з'явилася можливість зайняти лідируючі позиції в усіх категоріях напоїв в Україні, а для «Сандори» синергія виражається в придбанні потужних інвесторів, можливості працювати в новому ринковому сегменті, а також в отриманні досвіду з діяльності системи Pepsi в інших країнах.

Наступним прикладом зазначимо, що фактично основна мета створення спільного підприємства ЗАТ «Оболонь» та групи «Петросоюз» полягає у тому, щоб замкнути та оптимізувати ланцюг «виробництво - експортний збут» (зазначимо, що в вся продукція, вироблена в рамках створеного спільного підприємства на додаткових виробничих потужностях, буде експортуватись на ринок країн СНД); домогтись мінімізації собівартості продукції; забезпечити перехід до програм тотального управління якістю за рахунок 
тестування вихідної сировини та матеріалів, забезпечити їх високу якість.

Однією з основних переваг створення спільного підприємства для ЗАТ «Оболонь» $€$ використання спільних каналів збуту продукції на ринках країн СНД (в даному випадку це канали збуту групи «Петросоюз», яка зуміла налагодити ефективну систему збуту майже в усіх країнах СНД).

Негативний ефект (дисинергію) можна записати у вигляді такої нерівності «2+2<5». У цьому випадку синергетичний ефект може проявлятися через збільшення витрат за заданого рівня доходу, зменшення доходів за заданого рівня витрат або в разі зменшення доходів з одночасним збільшенням витрат. Ми вважаємо, що такий вплив має тоді, коли дія факторів макросередовища, елементів (та їх складових) укрупнення, інструментів концентрації виробництва (зокрема) має взаємно протилежне спрямування або не $\epsilon$ визначальною причиною для справжніх зрушень [9, С. 137].

Основна причина реструктуризації компаній у вигляді злиття i поглинань полягає в прагненні отримати та посилити синергетичний ефект. Як зазначають деякі вчені, синергетичне світобачення дозволяє по-новому підійти до проблеми ефективного управління розвитком складних систем (соціоприродних, екологічних, економічних) [8].

Суть синергетичної теорії полягає в тому, що при злитті нова корпорація може використовувати ряд переваг (синергій), які з'являються в результаті об'єднання ресурсів цих корпорацій. Синергетична теорія злиття ґрунтується на тому, що менеджери як корпорації-цілі, так і корпорації-покупця діють в найкращих інтересах своїх акціонерів, тобто усі їхні зусилля спрямовані на максимізацію добробуту останніх. У припущеннях синергетичної теорії менеджери корпорації-покупця та корпорації-продавця будуть зацікавлені в проведенні злиття тоді і тільки тоді, коли це злиття збільшує добробут їх акціонерів. Отже, основний мотив для менеджменту корпорації-покупця при проведенні злиття або поглинання полягає в спробі отримання синергетичних ефектів.

Синергетичний ефект в економіці може виникнути в результаті:

- операційної економії (операційної синергії), основними різновидами якої $\epsilon$ економія на масштабі, що проявляється в зниженні витрат на одиницю продукції, як правило, за рахунок зниження частки постійних витрат в загальному обсязі витрат, а також економія на охопленні, що виникає внаслідок можливості виробляти (надавати) більшу кількість найменувань товарів (послуг), використовуючи наявні основні фонди, сировину і матеріали. Як 
правило, саме цю мету переслідують корпорації в горизонтальних і вертикальних злиттях;

- ефекту агломерації, при якому витрати на одиницю продукції при отриманні доданої вартості стосовно до товару зменшуються на фіксований відсоток при кожному подвоєнні обсягу продукції (емпіричні дані показують, що темп зниження витрат на одиницю товару становить: для корпорацій автомобільної промисловості $12 \%$, сталеливарних і літакобудівних корпорацій - 20\%, для корпорацій, які спеціалізуються на виробництві напівпровідників, 40\% [5]);

- розширення номенклатури продукції, що випускається в результаті об'єднання окремих виробництв в загальну систему, і ефекту комбінування взаємодоповнюючих ресурсів (з одного боку, невеликі корпорації досить часто виробляють продукцію, якої потребують більш великі корпорації або корпорації, які хотіли б розширити свій виробничий асортимент за рахунок цієї продукції, але створення аналогічних власних виробництв було б для них економічно невигідним проєктом. 3 іншого боку, невеликі корпорації часто стикаються 3 проблемою нестачі фінансових ресурсів для фінансування своїх нових і вже існуючих проєктів). Таким чином, у результаті інтеграції компанії набувають відсутні у них ресурси і активи дешевше, ніж вони могли б обійтися при самостійному їхньому створенні кожною компанією;

- підвищення ефективності роботи 3 постачальниками в результаті придбання додаткового важеля зниження закупівельних цін шляхом збільшення сукупного обсягу закупівель і придбання тим самим можливості користуватися додатковими знижками або шляхом прямої загрози зміни постачальника. Наприклад, при зниженні витрат на постачальницьку діяльність всього на $10 \%$ цілком реально збільшити прибутковість компанії на 10-20\% [7, С. 16];

- різниці в ринковій ціні компанії і вартості їі заміщення: найчастіше простіше купити діюче підприємство ніж створити нове;

- зростання ринкової потужності через зниження конкуренції та можливості конкурувати за великі, в тому числі державні, контракти, отримання яких забезпечує високий рівень завантаження виробничих потужностей. Основним індикатором збільшення монополістичної потужності корпорації прийнято вважати отримання корпорацією більш високих прибутків в порівнянні 3 рештою корпорацій в галузі. Емпіричні дані свідчать, що збільшення частки ринку в середньому на 10\% супроводжується збільшенням прибутку на 5\% [5]. Зокрема, джерелом отримання більш високих прибутків 
може бути використання статусу «лідера ринку»: великі корпорації, що є лідерами своєї індустрії, ніколи не забувають згадати про цей факт у своїх рекламних компаніях, причина цього полягає в тому, що на покупців подібний статус має сприятливий вплив. Емпіричні дослідження поведінки купівельного попиту підтверджують: покупець оцінює продукцію за такими характеристиками, як кількість продукції, випущеної корпорацією, кількість років, протягом яких існує корпорація, їі репутація;

- прискорення руху компанії по стратегічній траєкторії: швидше вирішуються задачі росту (зростає швидкість розширення ринку, створення/зміцнення займаної ринкової ніші, створення нових продуктів). Синергетичний ефект, пов'язаний зі створенням стратегічних переваг, виділив Хіроюкі Ітамі в дослідженні в області підвищення ефективності використання ресурсів. Він пов'язує синергізм з використанням «ефекту безбілетника», коли ресурси, що акумулюються в одній частині компанії, використовуються одночасно і без будь-яких витрат іншими їі частинами. Прикладом такого синергізму $є$ використання сильної торгової марки для виведення на ринок нових товарів, використання сприятливого іміджу компанії для залучення клієнтів до нової продукції або використання наукових, виробничих та управлінських напрацювань у різних напрямках діяльності компанії, тобто до ресурсів, потенційно здатних до створення синергетичного ефекту, Ітамі відносить активи, засновані на інформації;

- збільшення політичного впливу компанії у регіоні / країні для відстоювання своїх інтересів, подолання законодавчих бар'єрів і обмежень та зниження національних ризиків за рахунок міжнародної диверсифікації [10, С. 312];

- пом'якшення впливу факторів ділового ризику, що може виражатися в зниженні розмаху коливань надходжень від продажу товарів та послуг, стабілізації притоку грошових коштів від операцій компанії за рахунок формування портфеля активів 3 різними життєвими циклами і об'єднання компаній різного профілю діяльності (ефект диверсифікації);

- фінансової економії: об'єднання компаній може внести вклад у зміцнення платоспроможності, поліпшити покриття виплат за позиковими коштами за рахунок додаткових грошових потоків, і, в кінцевому рахунку, призвести до зниження фінансового ризику компанії, а отже, до зниження витрат на капітал, здешевити його залучення і полегшити доступ до нього. Розмір компанії нерідко сам по собі $€$ гарантом стабільності і дозволяє отримати більш вигідний кредитний рейтинг: фінансові організації дорожать великими 
клієнтами, що дозволяє компанії ефективніше використовувати інструмент тиску. Нерідко вагомою причиною злиттів і поглинань $є$ скорочення податкових платежів у разі, коли високоприбуткова фірма, що несе високе податкове навантаження, набуває компанію $з$ великими податковими пільгами, які будуть використані для створеної корпорації в цілому. Фінансова синергія особливо чітко простежується в разі конгломеративного злиття. Так, у 1971 р. Вілбуром Левелленом було запропоновано чисту фінансову раціональність конгломеративного злиття, відому тепер також як ефект страхування корпоративного боргу. Левеллен показав, що злиття двох і більше корпорацій, потоки прибутку яких не корелюють між собою, знижує ризик дефолту за борговими зобов'язаннями нової корпорації і, отже, збільшує потенціал використання корпорацією боргового фінансування. Можливість збільшення боргового навантаження корпорації створює їі акціонерам добре відомий податковий щит - зменшення розмірів оподатковуваного прибутку, оскільки платежі за борговими зобов'язаннями у багатьох країнах віднімаються з оподатковуваного прибутку [6];

- фінансової синергії, теорія якої, що виправдує існування конгломератів, була запропонована в 1999 р. Флак і Лінчем. Теорія стверджує, що головним мотивом конгломератного злиття $є$ бажання однієї з компаній вирішити проблему браку ресурсів для проведення вигідного інвестиційного проєкту. Компанія 3 фінансовими труднощами, що має прибутковий інвестиційний проєкт (або цілу серію таких проєктів), в силу агентських проблем і асиметрично розподіленої інформації між менеджерами компанії та зовнішніми інвесторами, які вважають проєкт надмірно ризикованим, не може залучити фінансування під його проведення. У цій ситуації компанія вливається в конгломерат і там отримує необхідне фінансування. Більш формально фінансова синергія може бути визначена таким чином: обсяг фінансування, який може привернути конгломерат, завжди більше або дорівнює обсягу фінансування, який могли б залучити компанії-складові конгломерату, будучи окремими бізнесодиницями [7];

- диференційованої ефективності, яка означає, що управління однієї з фірм було неефективним і після злиття активи фірми стануть більш продуктивними [9, С. 403-404]. В економіці в цілому і в окремих іï галузях завжди можна знайти корпорації, поточна вартість яких занижена внаслідок неефективного управління іï активами поточним менеджментом, що може бути результатом нездатності або небажання менеджменту корпорації максимізувати ринкову вартість своєї компанії. Тут синергія розуміється як додаток 
Серія «Економічні науки»

Випуск 3(91) 2020 p.

управлінських здібностей менеджерів корпорації-покупця до неефективно використовуваних активів корпорації-цілі. Цей синергетичний ефект був відкритий в 1965 р. Генрі Манне [3, С. 313];

- вдосконалення корпоративної стратегії і культури, прояви ефекту об'єднання управлінських здібностей команди або командної синергії: в команді учасники відчувають себе в безпеці, вона дає відчуття належності до колективу, що $є$ дуже сильним мотивом, особливо для сучасної культури. Команда визнає і заохочує індивідуальні особливості своїх членів, внесок кожного в загальну справу, учасники розділяють почуття гордості за спільні досягнення. В результаті зовнішній світ вважає команду (корпорацію) більш потужною і впливовою соціальною одиницею;

- ефекту від перенесення компетенції: керуюча компанія може володіти унікальною компетенцією, управлінським «ноу-хау», вмінням створювати ефективні системи управління, здатним забезпечити конкурентоспроможність на ринку. При злитті дана компетенція переноситься на новопридбану бізнес-одиницю. Компанії, що «роблять ставку» на політику поглинань («компаніїрейдери»), прагнуть одержати доступ до комерційних секретів компаній-кандидатів на поглинання, що стосуються перспектив їх доходів, інформації про підготовку нових продуктів і контрактів [11];

- ліквідації дублюючих функцій (скорочення керуючого i обслуговуючого персоналу, а також ряду схожих функціональних підрозділів (бухгалтерія, управління фінансового контролю, дослідницькі та збутові підрозділи) і створення єдиних централізованих підрозділів, що призведе до значного зниження витрат на їх утримання. Наприклад, при реструктуризації холдингу «Сонячні продукти» (Саратов) були централізовані наступні функції: кредитування, закупівля сировини і матеріалів, а також юридична, фінансова і кадрова служби (в частині методологіі), виробничі служби (в частині бюджету капітальних витрат), дистрибуція і маркетинг. Однак слід враховувати той факт, що зайва централізація $€$ головною проблемою холдингових компаній. Як тільки топменеджмент починає централізовувати більшу частину управлінських функцій, у підрозділах настає параліч, вони не хочуть брати на себе відповідальність. Тож для географічно диверсифікованого бізнесу до зайвих повноважень центру треба ставитися дуже обережно [7, С. 17-18].

Здебільшого вартість синергії NPV визначається як різниця ринкових вартостей до $[V a+V b]$ та після $V a b$ концентрації [7, C. 123] і визначається за формулою

$$
N P V=V a b-[V a+V b] .
$$


Таких позицій дотримується більшість національних та зарубіжних науковців. У деяких наукових джерелах для оцінки синергетичних ефектів запропоновано використовувати термін «продовжена вартість» (continuing value), який тлумачиться як вартість підприємства після завершення інтеграційного періоду. Синергетичний ефект концентрації виробництва дорівнює різниці між продовженою та теперішньою вартістю концентрованого підприємства [5].

За підходом С. Майєрса та Р. Брейлі, синергетичний ефект слід розраховувати за формулою

$$
N P V=V a b-[V a+V b]-P-E,
$$

де NPV - чиста теперішня вартість; $V a b$ - ринкова вартість укрупненого підприємства; Va - ринкова вартість підприємства A; $\mathrm{Vb}$ - ринкова вартість підприємства Б; $P$ - премія виплачена за підприємство; $E$ - інші витрати.

Перетворивши рівняння за роботою П. Гохана, отримуємо формулу

$$
N P V=[V a b-(V a+V b)]-(P+E) \text {, }
$$

де $[V a b-(V a+V b)]$ - синергетичний ефект укрупнення підприємства; $(P+E)$ - сума премії та інших витрат.

Укрупнення буде успішним, якщо $[V a b-(V a+V b)]>(P+E)$.

В. Марченко вважає, що основою очікувань синергетичного ефекту $є$ ймовірність зростання вартості об'єднаного підприємства порівняно 3 перспективами щодо зростання вартості кожного окремого підприємства такого об'єднання. Умовою досягнення синергетичного ефекту вартості підприємства $€$ [7, С. 212]:

$$
e_{\gamma} \geq \frac{M_{a} e_{a}+M_{\beta} e_{\beta}}{M_{a}+M_{\beta}},
$$

де $e_{\gamma}$ - коефіцієнт, який відображає очікування 3 приводу зміни вартості підприємства за період $\Delta t$ у майбутньому; $M_{a}$ - вартість підприємства $A$ до концентрації; $M_{\beta}$ - вартість підприємства $Б$ до концентрації; $e_{a}$ - коефіцієнт, який відображає очікування з приводу зміни вартості підприємства $A$ за період $\Delta t$ в майбутньому; $e_{\beta}$ коефіцієнт, який відображає очікування з приводу зміни вартості підприємства Б за період $\Delta t$ в майбутньому.

Висновки. Оцінка синергетичного ефекту концентрації в промисловості дозволяє збільшити ступінь обґрунтованості рішення про здійснення цього процесу. Синергетичний ефект інтеграції можна визначити як отримання підприємством доданого 
Серія «Економічні науки»

Випуск 3(91) 2020 р.

економічного ефекту (або негативного результату), створеного в результаті включення в корпорацію нових підприємств.

Синергетичні ефекти від концентрації дуже різнорідні, тому автором пропонується класифікація синергетичних ефектів, що дозволяє врахувати як джерела виникнення синергій, так i їx відношення до структури грошових потоків корпорації та строками прояву.

1. Ansoff I. Corporate strategy : revised ed. London: Penguin Books, $1987.125 \mathrm{p}$. 2. KPMG : вебсайт. URL: http://www.kpmg.com. (дата звернення: 01.09.2020). 3. McKinsey \& Company : вебсайт. URL: http://www.mckinsey.com. (дата звернення: 01.09.2020). 4. Кемпбелл Э., Лачс К. С. Стратегический синергизм / пер. с англ. Е. Ковачева, А. Колос и др. 2-е изд. М., СПб, 2004. 414 с. 5. Кравець К. П. Методичні підходи до оцінювання ефектів концентрації виробництва. Регіональна економіка та управління : науково-практичний журнал. 2020. 1 (27). С. 128-137. 6. Кравець К. П. Удосконалення методичних підходів до оцінювання ефектів концентрації виробництва на підприємствах. Економічні студії. 2020. 1(27). С. 95-101. 7. Марченко В.М. Самоорганізація злиття та поглинання: умови та потенціал : монографія. К., 2011. 352 с. 8. Скопенко Н. С. Особливості формування комплексної системи ризик-менеджменту. Теоретичні та прикладні питання економіки : зб. наук. праць. 2016. Вип. 1(32). С. 33-43. 9. Britchenko I. \& Polishchuk Ye. Development of small and medium enterprises: the EU and East-partnership countries experience / Edited by Igor Britchenko and Yevheniia Polishchuk. Wydawnictwo Państwowej Wyższej Szkoty Zawodowej im. prof. Stanisława Tarnowskiego w Tarnobrzegu, 2018. 378 p. [in English]. 10. Illiashenko S. M. \& Strielkowski W. Managing economic growth: marketing, management, and innovations. Prague Institute for Qualification Enhancement. Prague, 2016. Vol. 1. 640 p. 11. Kravets K. P. Effects of ExportPromotional of the Food and Beverage Industry. 2019. URL: http://dspace.dgma.donetsk.ua (accessed: 22.08.2020).

\section{REFERENCES:}

1. Ansoff I. Corporate strategy : revised ed. London : Penguin Books, 1987. 125 p. 2. KPMG : vebsait. URL: http://www.kpmg.com. (data zvernennia: 01.09.2020). 3. McKinsey \& Company: vebsait. URL: http://www.mckinsey.com. (data zvernennia: 01.09.2020). 4. Kempbell Э., Lachs K. S. Stratehycheskii sinerhizm / per. s anhl. E. Kovacheva, A. Kolos y dr. 2-e yzd. M., SPb, 2004. 414 s. 5. Kravets K. P. Metodychni pidkhody do otsiniuvannia efektiv kontsentratsii vyrobnytstva. Rehionalna ekonomika ta upravlinnia : naukovo-praktychnyi zhurnal. 2020. 1 (27). S. 128-137. 6. Kravets K. P. Udoskonalennia metodychnykh pidkhodiv do otsiniuvannia efektiv kontsentratsii vyrobnytstva na pidpryiemstvakh. Ekonomichni studii. 2020. 1(27). S. 95-101. 7. Marchenko V. M. Samoorhanizatsiia zlyttia ta pohlynannia: umovy ta potentsial : monohrafiia. K., 2011. 352 s. 8. Skopenko N. S. Osoblyvosti formuvannia kompleksnoi systemy ryzyk-menedzhmentu. Teoretychni ta prykladni pytannia ekonomiky: zb. nauk. prats. 2016. Vyp. 1(32). S. 33-43. 9. Britchenko I. \& Polishchuk Ye. Development of small and medium enterprises: the EU and East-partnership countries experience / Edited by Igor Britchenko and Yevheniia Polishchuk. Wydawnictwo Państwowej Wyższej Szkoły Zawodowej im. prof. Stanistawa Tarnowskiego w Tarnobrzegu, 2018. 
378 p. 10. Illiashenko S. M. \& Strielkowski W. Managing economic growth: marketing, management, and innovations. Prague Institute for Qualification Enhancement. Prague, 2016. Vol. 1. 640 p. [in English]. 11. Kravets K. P. Effects of Export-Promotional of the Food and Beverage Industry. 2019. URL: http://dspace.dgma.donetsk.ua (accessed: 22.08.2020).

Fedun I. L. [1 ORCID ID: 0000-0002-1012-9970],

Doctor of Economics, Professor

Kravets K. P. [1; ORCID ID: 0000-0002-6850-9378] Candidate of Economics (Ph.D.), Associate Professor

${ }^{1}$ Kyiv National University of Trade and Economics, Kyiv, Ukraine

\section{SYNERGISTIC EFFECTS IN PROCESS OF CONCENTRATION PRODUCTION}

The article considers the theoretical aspects of the manifestation of synergistic effects in modern concentration processes. The main forms of manifestation of synergistic effects on the example of the food industry are investigated. The main forms of manifestation of synergetic effects are considered. Theoretical approaches to the concept of satiety «synergetics» and «synergetic effects» are formed. Methodical tools for the study of synergetic effects are presented. Synergetic effects in terms of positive and negative results are considered. Consider the essence of the concept of «effect of concentration of production». Indicators of the effect reflect the degree of implementation of the main tasks of the enterprise: production to meet the needs of consumers; sales volume; market share of the enterprise; the cost of the enterprise; production capacity of the enterprise. It should also be noted that a high level of concentration of production does not guarantee high economic efficiency of production. Excessive concentration can lead to loss of control of the organization. In addition, if the company has a large size, irrational structure of fixed assets, suboptimal range of products, the level of concentration can not serve as an indicator of production efficiency. In each specific industry there are the most optimal sizes of the enterprises, objectively caused by the mechanism of formation of economic effect of concentration (scale). The optimal size should be understood as the most effective size of the enterprise. The criterion of economic efficiency of the optimality of enterprises is the minimum reduced costs of production and specific capital investment. The results of numerous studies show that the main reasons for failures in most cases of consolidation were the overestimation of the synergistic effect and the underestimation of costs in the preparation of the operation. After all, about $70 \%$ of mergers and acquisitions have not achieved the planned synergy effect from the merger. Therefore, companies must carefully analyze the possibilities of creating a synergetic effect and ensure maximum 
cooperation in the areas of its emergence. According to the theory, consolidations, in which the realization of the synergetic effect is expected, should increase the welfare of the company's shareholders. The problem is that the synergistic effect is difficult to predict, and in practice it is not always possible to achieve the expected result. The synergistic effect of the concentration of production is a combination of elements in which the potential will exceed or decrease the sum of the potentials included in its elements.

Keywords: concentration of production; synergy; synergistic effects; food industry.

Федун И. Л. [1 ORCID ID: 0000-0002-1012-9970], д.э.н., профессор кафедры мировой экономики

Кравец Е. П. [1; ORCID ID: 0000-0002-6850-9378], к.э.н., доцент кафедры мировой экономики

${ }^{1}$ Киевский национальный торгово-экономический университет, г. Киев

\section{СИНЕРГИЧЕСКИЕ ЭФФЕКТЫ В ПРОЦЕССАХ КОНЦЕНТРАЦИИ ПРОИЗВОДСТВА}

В статье рассмотрены теоретические аспекты проявления синергетических эффектов при современных концентрационных процессах. Исследованы основные формы проявления синергетических эффектов на примере пищевой промышленности. Рассмотрены основные формы проявления синергетических эффектов. Сформированы теоретические подходы к понятию сути «синергетика» и «синергетические эффекты». Приведен методический инструментарий исследования синергетических эффектов. Рассмотрены синергетические эффекты в разрезе положительного и отрицательного результата. Рассмотрена сущность понятия «эффект концентрации производства». Показатели эффекта отражают степень реализации основных задач деятельности предприятия производство продукции для удовлетворения потребностей потребителей; объем продаж; доля рынка предприятия; стоимость предприятия; производственная мощность предприятия. Необходимо также отметить, что высокий уровень концентрации производства еще не гарантирует высокую экономическую эффективность производства. Чрезмерная концентрация может привести к потере управляемости организации. Кроме того, если предприятие имеет большие размеры, нерациональную структуру основных средств, неоптимальную номенклатуру производимой продукции, то уровень концентрации не может служить показателем эффективности производства. В каждой конкретной отрасли есть наиболее оптимальные размеры предприятий, объективно обусловленные механизмом 
образования экономического эффекта концентрации (масштаба). Под оптимальными размерами следует понимать наиболее эффективные размеры предприятия. Критерием экономической эффективности оптимальности предприятий является минимум приведенных затрат на производство продукции и удельных капитальных вложений. Результаты многочисленных исследований свидетельствуют, что основные причины неудач в большинстве случаев укрупнения заключались в переоценке синергетического эффекта и недооценке расходов на этапе подготовки операции. Ведь около $70 \%$ сделок по слиянию и поглощению не достигают запланированного синергетического эффекта от объединения. Следовательно, предприятия должны тщательно анализировать возможности создания синергетического эффекта и обеспечить максимальное сотрудничество в сферах его возникновения. Согласно теории, укрупнения, в которых ожидается реализация синергетического эффекта, должны увеличивать благосостояние акционеров предприятия. Проблема заключается В том, что синергетический эффект трудно поддается прогнозированию, и на практике не всегда удается достичь ожидаемого результата. Синергетический эффект концентрации производства заключается в сочетании таких элементов, при которых потенциал будет превышать/снижать сумму потенциалов, входящих в его элементов.

Ключевые слова: концентрация производства; синергия; синергические эффекты; пищевая промышленность. 